\title{
Three-Dimensional Structure of the mesoscale eddies in the Agulhas Current region from hydrological and altimetry data
}

\author{
N. V. Sandalyuk ${ }^{1}$ and T. V. Belonenko ${ }^{1}$ \\ Received 29 October 2020; accepted 31 March 2021; published 27 August 2021.
}

In this work by implementing the method of colocalization the altimetry data and temperature and salinity profiles we provide a detailed study of the averaged thermohaline structure of the anticyclonic and cyclonic mesoscale eddies formed in the southern part of the Agulhas Current system. The observed intensification of eddy dissipation processes can be caused by the topographic barriers, such as the Agulhas Plateau or the Agulhas Ridge. In the eddies of both polarities significant temperature anomalies are concentrated within the distance of one radius from the eddy center and to the depth of $\sim 1500 \mathrm{~m}$. The obtained averaged estimates of heat and salt transported by the Agulhas Rings is $2.38 \times 10^{20} \mathrm{~J}$ and $4.79 \times 10^{12} \mathrm{~kg}$ respectively. Westward propagation of the zonal eddy-induced transport for anticyclonic and cyclonic eddies is observed in the Agulhas Retroflection region, Cape Basin and in the central part of the shelf zone with the maximum values of $4 \mathrm{~Sv} / \mathrm{deg}^{2}$ for anticyclonic eddies and $1.77 \mathrm{~Sv} / \mathrm{deg}^{2}$ for cyclonic eddies. KEYWORDS: Agulhas Rings; Agulhas Current; mesoscale eddies; altimetry; three-dimensional structure.

Citation: Sandalyuk, N. V. and T. V. Belonenko (2021), Three-Dimensional Structure of the mesoscale eddies in the Agulhas Current region from hydrological and altimetry data, Russ. J. Earth. Sci., 21, ES4005, doi:10.2205/2021ES000764.

\section{Introduction}

Although mesoscale eddies are ubiquitous in the World Ocean [Chelton et al., 2007, 2011], the areas of highest eddy activity are confined to the regions of large-scale currents due to the baroclinic and barotropic instability, which is one of the main conditions for eddy generation [Monin and Zhikharev, 1990. In the Southern Hemisphere, such currents are the Brazilian, East Australian, Antarctic Circumpolar Current, and the Agulhas Current.

In this work, we provide a detailed study of the general thermohaline structure of the mesoscale eddies formed in the southern part of the Agulhas

\footnotetext{
${ }^{1}$ Saint Petersburg State University, St. Petersburg, Russia

Copyright 2021 by the Geophysical Center RAS. http://rjes.wdcb.ru/doi/2021ES000764-res.html
}

Current system. This region is one of the most dynamically complex areas of the World's Oceans. It is characterized by the high variability of thermohaline fields over a wide range of space-time scales [Lutjeharms, 2006] Lutjeharms and Ballegooyen, 1988 .

In the Agulhas Retroflection area, the Agulhas Current turns back on itself and flows eastward forming a loop from which the large anticyclonic rings are detaching (Figure 1). These rings are responsible for the transfer of warmer and saltier Indian Ocean waters to the South Atlantic [Lutjeharms and Ballegooyen, 1988, Lutjeharms and Valentine, 1988]. The main distinctions of the Agulhas Rings from other eddies are larger spatial scales, longer lifespans, and their predominant northwestern propagation direction [Boebel et al., 2003. Dencausse et al., 2010, Lutjeharms, 2007. Malysheva et al., 2018, Sandalyuk et al., 2018; van Sebille and van Leeuwen, 2007. 


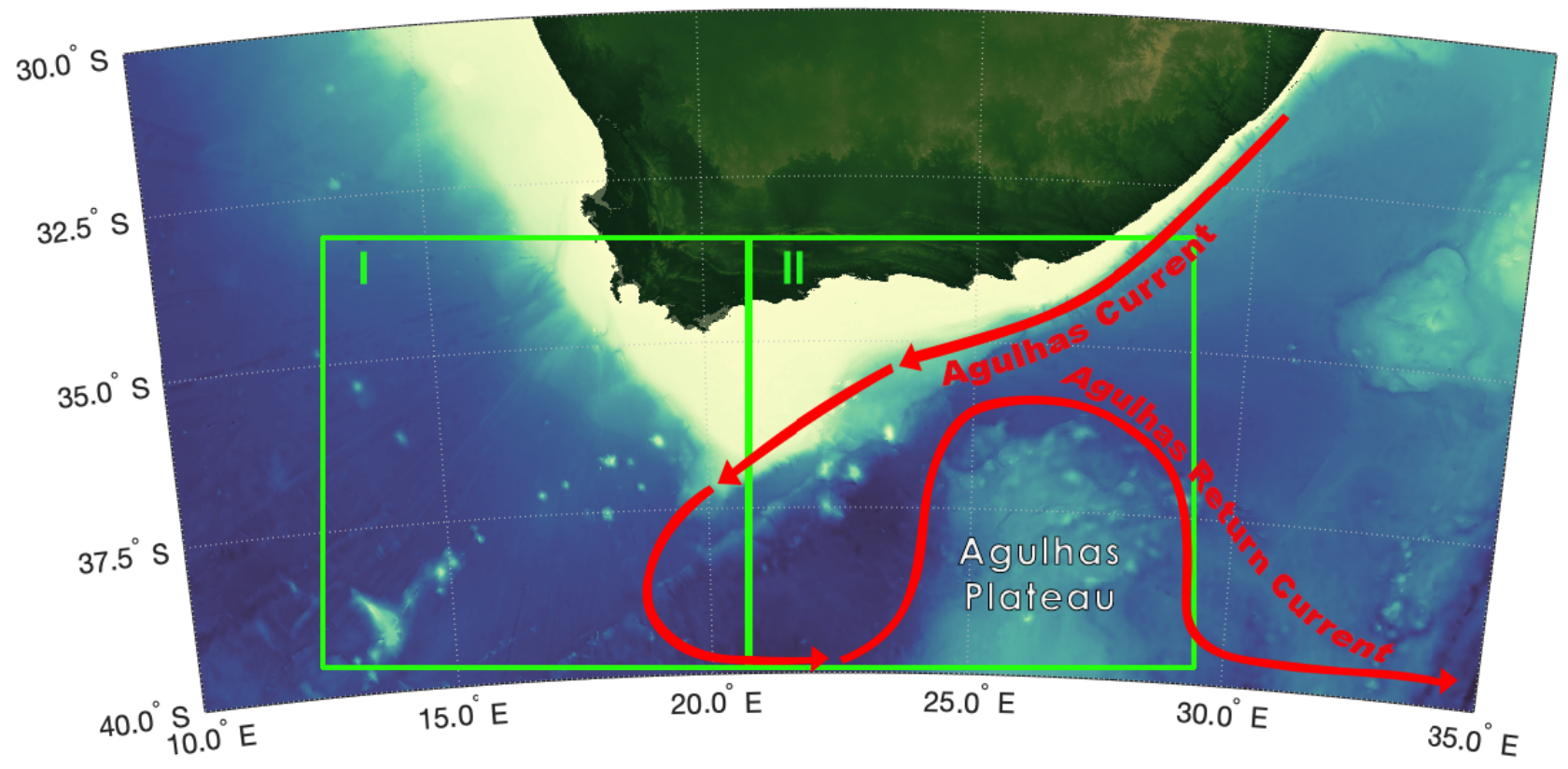

Figure 1. Agulhas Current region with the bathymetry (ETOPO1 1 Arc-Minute Global Relief Model) and schematic path of the Agulhas Current system. I and II - regions selected for the analysis of the composite eddy structure.

The Agulhas Rings have previously been investigated in a number of studies [e.g. van Ballegooyen et al., 1994, Byrne et al., 1995, Gordon et al., 1987, Laxenaire et al., 2019, McCartney and WoodgateJones, 1991, Schouten et al., 2000, Schmid et al., 2003. These studies confirm the crucial role of the Agulhas Rings in the Indo-Atlantic interocean exchange of heat and salt.

It should be noted that in previous studies the thermohaline structure of the Agulhas Rings has been analyzed on the example of the individual eddies while in our study we evaluate the eddy structure by obtaining composite anticyclonic eddy, which represents the averaged structure of the Agulhas Rings. A similar technique for studying Agulhas Rings was implemented in the work of Souza et al. 2011. In our research, we use results of the new advanced eddy automatic identification method, which covers a wider time range and significantly larger amount of profiles.

In this paper we focus on the general thermohaline structure of the Agulhas Rings and their contribution to the heat and salt transport in the study region. However, we also asses the threedimensional structure of the anticyclonic eddies which form in the Agulhas Current region but not associated with the Agulhas Rings. Moreover, we analyze three-dimensional structure of the cyclonic eddies forming in the study region.

\section{Data and Methods}

\subsection{Mesoscale Eddy Trajectory Atlas Product}

To identify the position of mesoscale eddies and track their propagation, the "Mesoscale Eddy Trajectory Atlas Product" data set was used. This data set based on the algorithm developed by Chelton et al. 2011 and applied to SLA fields from merged multimission satellite measurements. The algorithm was modified as described in Schlax and Chelton 2016 based on the approach described by Williams et al. 2011. The "growing" method of eddy identification defines the anticyclonic eddy interior by finding a local maximum in SLA and all neighboring pixels whose SLA values lie above a sequence of decreasing thresholds. This "growth" of the eddy interior is continued until at least one of the criteria for this coherent structure is violated. Cyclonic eddies are defined in the same way 
by finding the local minimum of SSH [Schlax and Chelton, 2016. The dataset is now routinely generated and quality-controlled by the Data Unification and Altimeter Combination System (DUACS) and distributed by AVISO+. The dataset and the documentation with a detailed description of the modified algorithm are available at https://www.aviso.altimetry.fr. The final version of the dataset contains the location of detected eddies on each day for the whole altimetry period (1993-ongoing).

\subsection{ARGO Data}

To construct three-dimensional composite structure of mesoscale eddies in the Agulhas Current system region, the ARGO temperature and salinity profiles were used. The data is available at the Coriolis Data Center website (http://www.coriolis. eu.org/Observing-the-Ocean/ARGO). Only profiles flagged "ADJUSTED" were used in the research. It is a delayed mode data which means that profiles have been subjected to detailed scrutiny by oceanographic experts and the adjusted salinity has been estimated by comparison with highquality ship-based CTD data and climatologies. Only profiles with pressure, temperature, and salinity data flagged as good were used in the analysis. In addition, the more rigorous quality control was implemented to exclude "suspicious" profiles. The profiles with the last record shallower than 500 $\mathrm{m}$ were eliminated [Chaigneau et al., 2011, He et al., 2018. After the implementation of all levels of quality control, the 9179 profiles were obtained for the study region for the period of 2000-2018. The retained profiles were linearly interpolated onto $5 \mathrm{~m}$ regular grid: from 0 to $1500 \mathrm{~m}$.

\subsection{Construction of the Composite Three-Dimensional Structures}

The method of colocalization the altimetry and in situ data was presented in Willis and Fu 2008 and Chaigneau et al. 2011 and been extensively used in a number of studies covering different regions of the World Ocean [e.g. Dong et al., 2017, He et al., 2018, Keppler et al., 2018, Kubryakov et al., 2018, Sandalyuk et al., 2020, Yang et al., 2013, Yu et al., 2017.
Each selected profile was associated with the nearest eddy if it satisfied the two following conditions: (1) The profile and the eddy have the same observation day; (2) The profile located within a distance less than the eddy radius $R$ derived from the "Mesoscale Eddy Trajectory Atlas Product". The distance between the location of the profile and the eddy center was normalized by the radius $R$. Normalized distance 0 corresponds to the eddy center while normalized distance 1 corresponds to the eddy maximum velocity average within the contour defining the eddy. This approach is based on the assumption made by Zhang et al. 2013 that all eddies, regardless of their amplitude, polarity or scale have the same structure, therefore we can expect that the dependence of the eddy's thermohaline structure on its radius is universal for eddies of different scales. Subsequent works that followed that technique confirmed the feasibility of this approach [e.g. He et al., 2018, Kubryakov et al., 2018. Keppler et al., 2018, Sandalyuk et al., 2020. However, we increase the size of the composite eddy to $1.5 R$ as the presence of eddies also influences its vicinity [He et al., 2018].

Analyzed profiles were classified into two groups depending on the vorticity sign: anticyclonic (AE) and cyclonic $(\mathrm{CE})$. The total number of profiles located within the distance of $1.5 R$ from the center for AEs and CEs is 1193 and 1159. Figure 2 displays the distribution of the obtained profiles in the normalized eddy-coordinate system.

In order to better understand the vertical thermohaline structure of the mesoscale eddies and estimate zonal transport induced by CEs and AEs, the temperature $\left(T^{\prime}\right)$ and salinity $\left(S^{\prime}\right)$ anomalies were calculated by subtracting monthly local mean climatological $T / S$ profiles from $T / S$ profiles associated with the eddies. The mean climatology was computed from the hydrographical data set within $2.5 R$ around each eddy observation. To construct three-dimensional composite eddy structure retained $T^{\prime} / S^{\prime}$ profiles were finally interpolated onto a regular $0.1 \times 0.1 R$ grid at each depth level ( $5 \mathrm{~m}$ ) using Barnes objective analysis with the smoothing length scale of 0.5 for both radial and vertical axis [Barnes, 1973, Keppler et al., 2018.

To achieve an estimation on spatial distribution of the zonal and meridional eddy induced volume transport we follow the approach of Dong et al. 2017, who proposed a new method for eddy heat and salt transport evaluation using eddy 

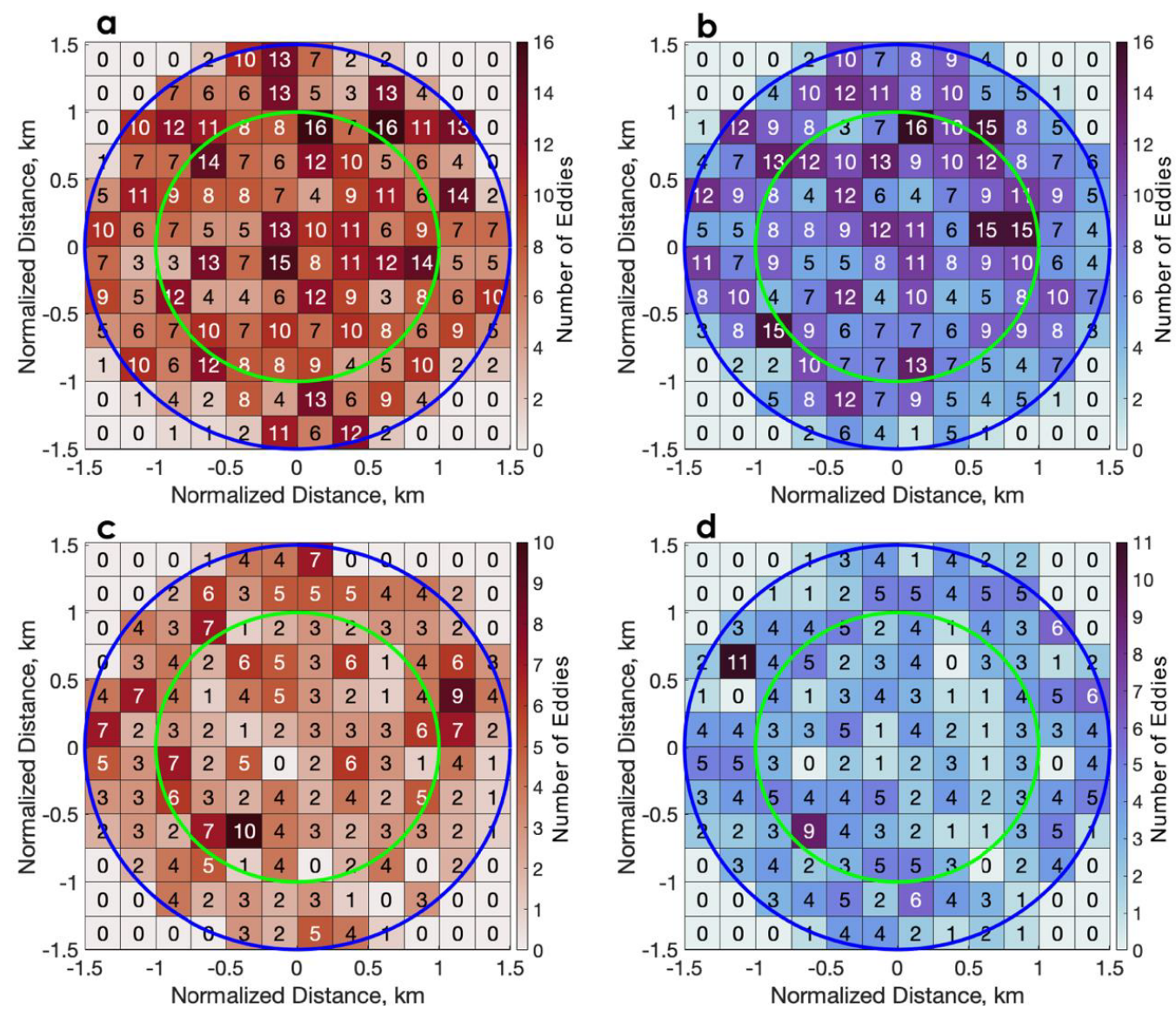

Figure 2. The distribution of the obtained profiles in the normalized eddy-coordinate system calculated in the $0.25 R \times 0.25 R$ bin associated with AEs (a, c) and CEs (b, d) eddies, in the Region I (a, b) and II (c, d). The green and blue circles indicate distance of $1 R$ and $1.5 R$ from the eddy center respectively.

trajectories instead of propagation velocity [e.g. Dong et al., 2014. Taking into account the spatial resolution of SLA gridded data and difference in size between latitude and longitude for the study region, the study area was divided into $1^{\circ} \times 0.8^{\circ}$ grid cells. For every cell, the number of eddies crossing the cell boundaries were tracked (i.e., western/eastern boundary for zonal transport and northern/southern boundary for meridional transport).

Transport $(D)$ is calculated as $D=(V N) / M$, where $D$ is the volume of water transported by a single composite eddy, $N$ is the number of detected eddies that crossed the cell boundary and $M$ is the time of the analysis period. Westward and northward transports are defined as positive. For every cell the zonal (resp., meridional) volume transport was calculated as an average between transports of the western and eastern (resp., northern and southern) borders of the cell.
Since the properties of rings formed in the Agulhas Retroflection region may significantly differ from the mesoscale eddies which form in other parts of the Agulhas Current System the study region was divided into the two subregions $($ Figure 1). Region I defined as $13^{\circ}-22^{\circ} \mathrm{E}, 34^{\circ}-41^{\circ} \mathrm{S}$. It includes the Agulhas Leakage region and southeastern part of the Cape Basin, which has been referred in the previous studies as the Cape Cauldron [Boebel et al., 2003. Generation sites and most of the propagation trajectories of the Agulhas Rings are bordered by the Region I [Dencausse et al., 2010, Malysheva et al., 2018]. Region II includes eddies formed in the area of Agulhas Return Current as well as eddies formed in the northeastern part of the shelf zone $\left(22^{\circ}-28^{\circ} \mathrm{E}, 34^{\circ}-41^{\circ} \mathrm{S}\right)$. This region is influenced by the juxtaposition of the Agulhas Return Current with the Subtropical Convergence Zone [Boebel et al., 2003. For every selected region, trajectories of eddies formed in this 
region were taken into account. Thus, we exclude any possible influence on the final result of eddies formed outside the boundaries of the selected region.

\section{Mean Eddy Properties}

Since the data set we use contains the latest information about the eddy properties we think it is necessary to refresh basic eddy statistics for the study region.

A total number of 2651 of eddies (1350 CEs and $1301 \mathrm{AEs}$ ) were detected in the study region for the period 1993-2018. The mesoscale eddies of both polarities are ubiquitous in the Agulhas region (Figure 3). The coastal zone is an exception but zero values here can be explained by the gaps in the SLA fields near the coast due to the errors in SLA data in these areas. The maximum density of AEs is observed in the northeastern part of the shelf (Figure 3 , Figure $3 \mathrm{~d}$ ). The density of both AEs and CEs is minimal in the southern part of the shelf zone.

The patterns of eddy generation (locations where eddies were first detected by automatic identification algorithm) are presented in Figure 3a, Figure $3 \mathrm{~b}$. In general, eddies are formed almost everywhere in the study region. However, eddies are most frequently observed in the area to the west of the Agulhas Plateau $\left(22^{\circ}-24^{\circ} \mathrm{E}\right)$, in the Agulhas Retroflection region, and in the eastern part of the shelf zone. The latter pattern of the eddy genesis can be linked to the strong baroclinic instability of the Agulhas Current near the shelf area [Wells et al., 2000. The geographic distribution of eddy genesis for the AEs and CEs is generally similar, but CEs are formed closer to the western extremity of the Agulhas Plateau (Figure 3b).

The spatial patterns of eddy dissipation are presented in Figure 3e, Figure 3f). The main "eddy graveyards" are located to the west and to the east of the longitude band $20^{\circ}-23^{\circ} \mathrm{E}$. The eastern area of the shelf zone is also characterized by the high intensity of the dissipation processes. The patterns of eddy dissipation for both AEs and CEs can be linked to the topographic barriers, such as the Agulhas Plateau or the Agulhas Ridge, which cross the typical trajectories of the eddy propagation in the study area. This confirms the conclusions of previous studies about the significant influence of bottom topography on the eddy propagation and dissipation in the Agulhas region [Hall and Lutjeharms, 2011; Schouten et al., 2000.

The average lifespan of the eddies formed in the study region is 132 days but it varies in the wide range and can reach 800 days. We normalize the eddy parameters by their lifetime where normalized lifetime 0 corresponds to the beginning of the eddy lifecycle, while normalized lifetime 1 corresponds to the end of the eddy lifespan. Thus, we obtain the distribution of the eddy parameters as a function of lifetime which allows us to analyze the time evolution of the mean eddy parameters for the study region (Figure 4).

Radius, amplitude and circum-averaged speed of the eddies of both polarities (Figure 4 , Figure $4 b$, Figure 4d) show dome-shape patterns of their temporal evolution with the minimum at the beginning of the eddy lifecycle. On the contrary, the propagation speed $(\sim 9 \mathrm{~cm} / \mathrm{s})$ is the strongest at the beginning of the eddy lifespan and rapidly decreases in the first $20 \%$ of the eddy lifecycle. The radius and circum-averaged speed of the AEs is larger than that of CEs throughout the eddy lifecycle while the amplitude of the CEs is mostly larger than for the AEs except at the first and last $5 \%$ of the eddy lifetime.

\section{Radial Cross-Sections of the Composite Eddies}

To analyze the vertical thermohaline structure of AEs and CEs in the study region the radial composite sections of temperature, salinity, and density anomalies were constructed based on the obtained three-dimensional composite structures. The radial cross-sections were calculated separately for Region I and II. Significant eddy-induced $T^{\prime} / S^{\prime}$ anomalies are concentrated within the distance of one radius $R$ from the eddy center. It should be also noted that composite eddies of both polarities significantly influence the thermohaline characteristics at the horizontal distance up to at least $1.5 R$ from the eddy center (Figure 5, Figure 6).

\subsection{Radial Cross-Sections in the Region I}

The positive temperature anomalies in the composite $\mathrm{AE}$ are concentrated within the depth range of $100-700 \mathrm{~m}$. The eddy core is located at a depth 

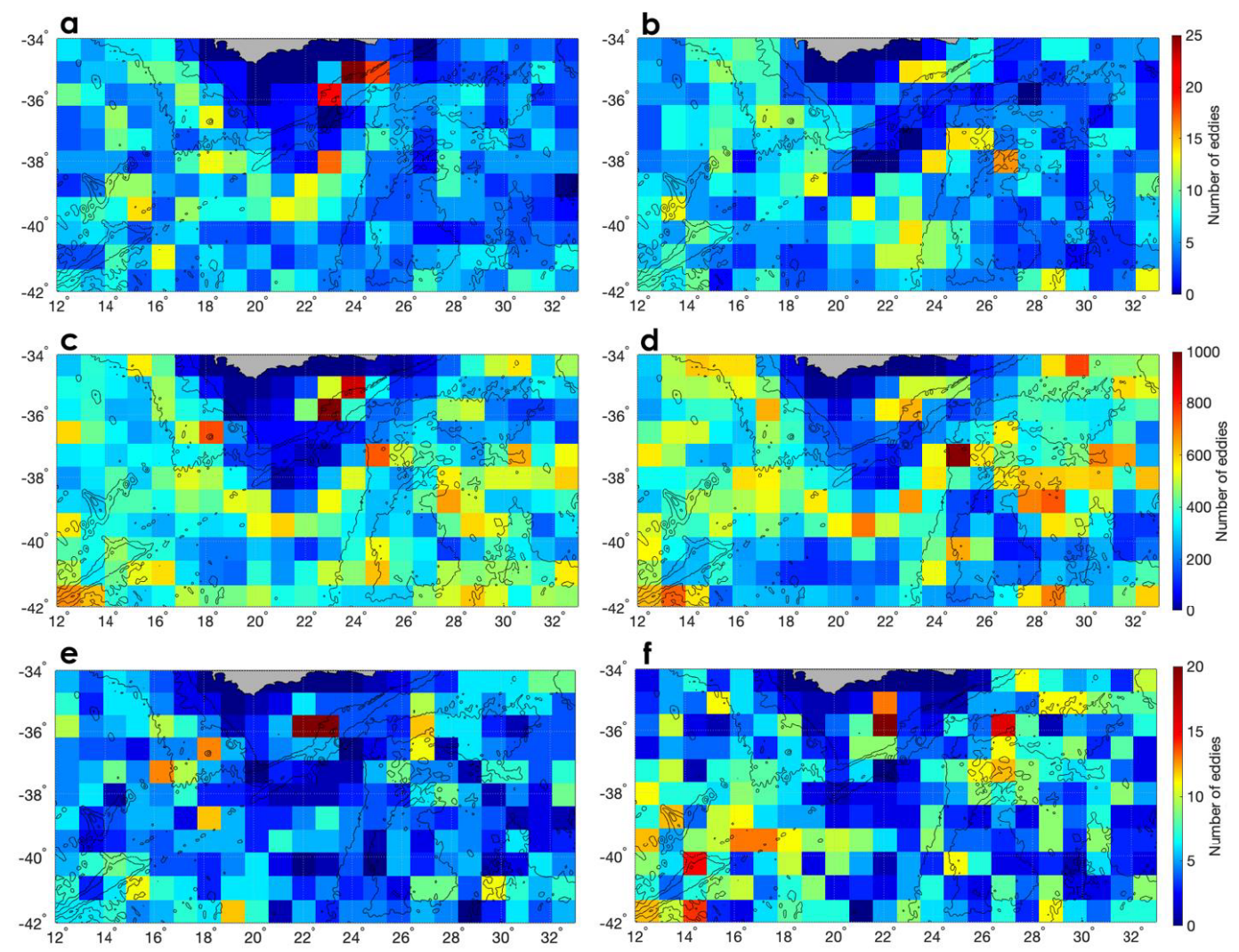

Figure 3. Geographic distributions of eddy genesis (a, b) occurrence (c, d) and dissipation $\left(\mathrm{e}, \mathrm{f}\right.$ ) for the AEs (a, c, e) and CEs (b, d, f) (number of eddies for every $1^{\circ} \times 0.8^{\circ}$ bin for the period 1993-2018).

of $200 \mathrm{~m}$ with a maximum of about $1.94^{\circ} \mathrm{C}$ (Figure 5a). The penetration depth of the positive temperature anomalies in the composite $\mathrm{AE}$ reaches $1500 \mathrm{~m}$. Nevertheless, even at the maximum depth of $1500 \mathrm{~m}$, the temperature anomaly is no less than $0.2^{\circ} \mathrm{C}$. The distribution of the salinity anomalies in the composite AE shows a similar pattern. However, the maximum penetration depth of salinity anomalies reaches $900 \mathrm{~m}$ (Figure 5b) which is significantly smaller than for the temperature anomalies. The maximum salinity anomaly is located at a depth of $400 \mathrm{~m}$ and equals $0.23 \mathrm{~g} / \mathrm{kg}$. The radial density structure of the composite AE mostly follows the temperature anomaly pattern with the maximum located at the depth of $\sim 200 \mathrm{~m}$. The negative density anomaly reaches the depth of $1500 \mathrm{~m}$ (Figure 5c).

The layer 150-700 m (Figure 5d) bound the core of the composite CE. The minimum value of temperature (salinity) anomaly is at a depth of $450 \mathrm{~m}$ $(350 \mathrm{~m})$ and equals $-2.5^{\circ} \mathrm{C}(-0.25 \mathrm{~g} / \mathrm{kg})$ (Figure 5 e). The penetration depth of significant salinity and temperature anomaly in the composite $\mathrm{CE}$ is 1500 and $800 \mathrm{~m}$ respectively.

\subsection{Radial Cross-Sections in the Region II}

Figure 6 shows the radial cross-sections of the composite eddies for Region II (Figure 1). The temperature core in the composite $\mathrm{AE}$ is located in the depth range of 200-800 m (Figure 6a) with a maximum value of $1.17^{\circ} \mathrm{C}$ located at the $600 \mathrm{~m}$. The maximum salinity anomaly is $0.15 \mathrm{~g} / \mathrm{kg}$ at a depth of $400 \mathrm{~m}$ (Figure $6 \mathrm{~b}$ ). The vertical penetration depth of significant temperature/salinity anomalies for the composite AE and CE is 1400/800 $\mathrm{m}$ and $1250 / 700 \mathrm{~m}$ respectively.

The depth of the eddy core in the composite $\mathrm{CE}$ is about $400 \mathrm{~m}$ (Figure $6 \mathrm{~d})$ with the minimum temperature and salinity anomaly of $-1.38^{\circ} \mathrm{C}$ and $-0.17 \mathrm{~g} / \mathrm{kg}$ located at the $400 \mathrm{~m}$ and $250 \mathrm{~m}$ respectively. The eddy core also manifests itself in the density field (Figure 6 ).

Although the general thermohaline structure of the radial cross-sections for the composite AE and CE shows a similar to Region I pattern, the average 

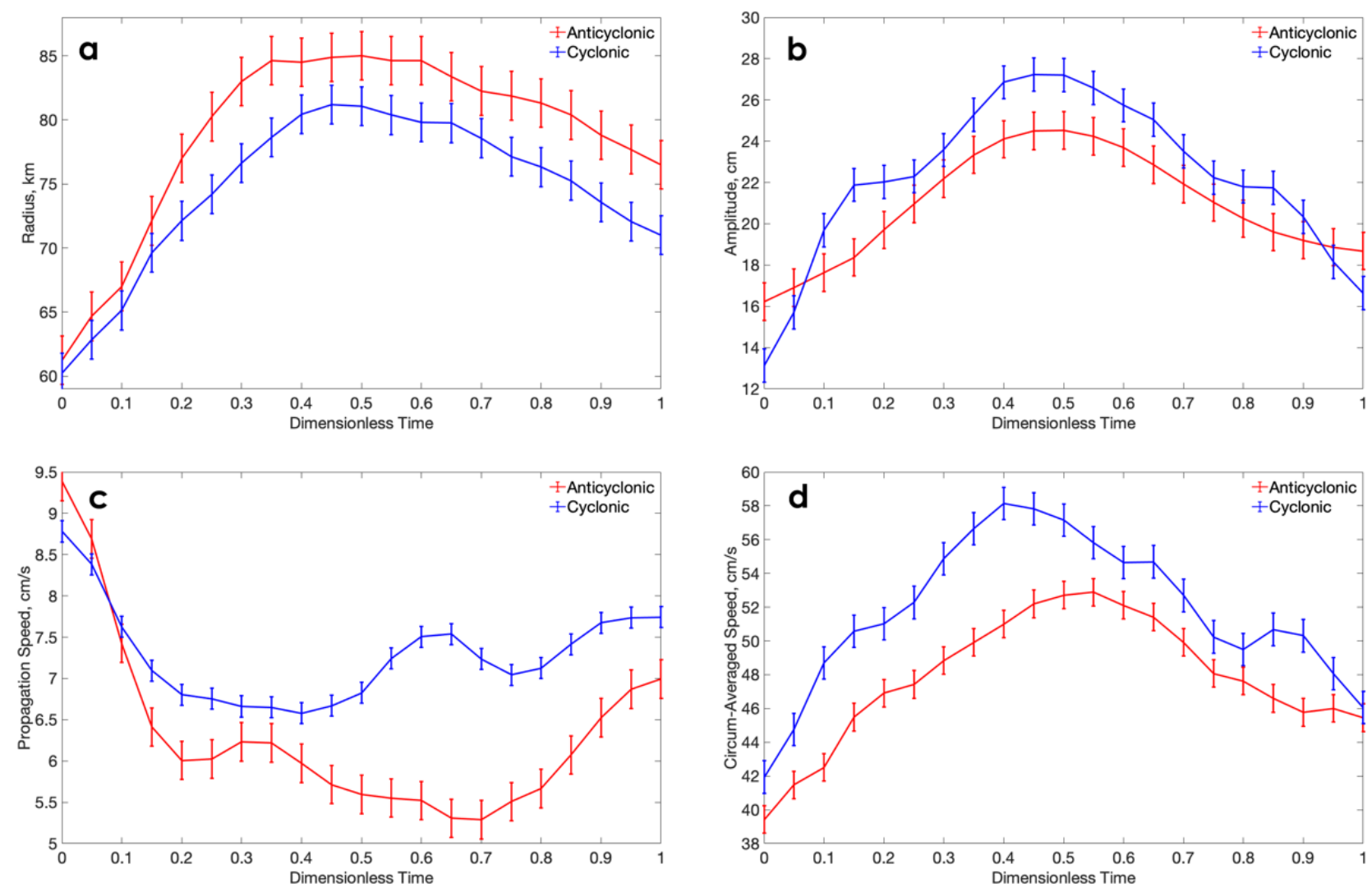

Figure 4. Mean eddy radius (a), amplitude (b), propagation speed (c) and circumaveraged speed as a function of the normalized eddy lifetime. The error bars denote the standard error of the mean.

$T^{\prime} / S^{\prime}$ values for the two regions differ significantly. Maximum $T^{\prime} / S$ values for the composite $\mathrm{AE}$ in Region I are $\sim 1.5$ times higher than maximum $T^{\prime} / S$ values for the composite AE in Region II. Similar ratios are observed for the average $T^{\prime} / S$ values of the composite $\mathrm{CE}$ from the two regions.

\section{Three-Dimensional Structures of the Composite Eddies}

Figure 7, Figure 8 show three-dimensional structures of a composite $\mathrm{AE}$ and $\mathrm{CE}$ for Region I and horizontal distributions of temperature and salinity anomalies at selected depth levels. The shape of the AE core is close to symmetrical and maximum values of the temperature and salinity anomalies are concentrated in the geometrical center of the eddy (Figure 7). The core of the composite AE has a distinctive structure which is promi- nent feature of the Agulhas Rings [Laxenaire et al., 2019. Starting from a depth of about $500 \mathrm{~m}$ the eddy signature in the temperature and salinity fields is gradually decreasing. This reduction manifests itself both in the decreasing of temperature/salinity anomalies with depth and in the decreasing of the distribution of significant $\left(>0.1^{\circ} \mathrm{C}\right)$ anomalies from the eddy center. At the depth of $1000 \mathrm{~m}$, significant temperature anomalies extend at the distance of $0.5 R$.

There is a small asymmetry in the three-dimensional structure of the AE. Temperature extrema are shifted at $\sim 0.25 R$ to the north from the eddy center (Figure 8). This asymmetry is gradually decreasing with depth and insignificant at the $800 \mathrm{~m}$. It should be also noted that in both composite $\mathrm{AE}$ and $\mathrm{CE}$ in the surface layer (down to $50 \mathrm{~m}$ ) the temperature and salinity anomalies almost undetectable and sharp increase of the thermohaline anomalies starts from the depth level of about $100 \mathrm{~m}$. This pattern can be tracked in both 

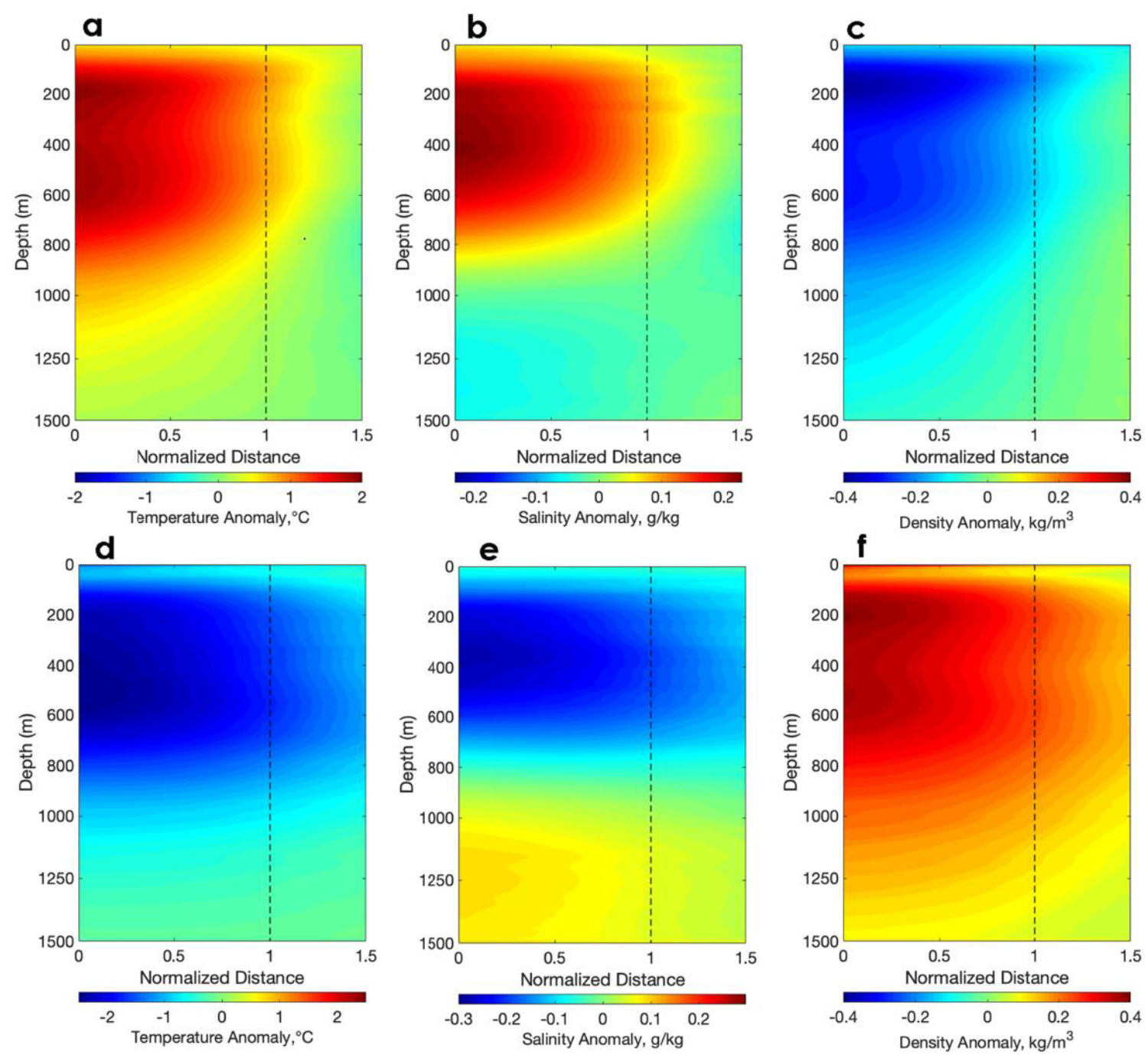

Figure 5. Radial cross-sections of temperature (a, d), salinity (b, e) and density (c, f) anomalies in the composite AE (top) and CE (bottom) (Region I).

radial cross-sections and three-dimensional structures (Figure 7, Figure 8). Laxenaire et al. 2019 showed that for the eddies in the Agulhas region in the layer of $\sim 0-150 \mathrm{~m}$ the strong seasonal signal is observed and specifically for the Agulhas Rings the water in this layer is not a part of the eddy core.

The composite AE in the Region II has an asymmetric spatial distribution of $T^{\prime} / S^{\prime}$ values with extremum (maximum of $T^{\prime} / S^{\prime}$ ) shifted at $\sim 0.5 \mathrm{R}$ to the northwest direction relative to the eddy center (Figure 9). The observed shift gradually decreasing with depth and equals about $0.25 \mathrm{R}$ at the 500 m. The opposite extremum (minimum of $T^{\prime} / S^{\prime}$ ) of about $-2^{\circ} \mathrm{C} /-0.2 \mathrm{~g} / \mathrm{kg}$ is observed in the southeastern part of the composite eddy (Figure 9). The spatial distribution of the thermohaline anomalies in the composite CE in the Region II (Figure 10) shows the similar symmetrical pattern with the composite $\mathrm{CE}$ in the Region I.

Figure 11 shows the vertical profiles of the temperature, salinity and density anomalies obtained by the horizontal averaging of all profiles located within the distance of $1 \mathrm{R}$ from the centers of AEs and CEs for the Regions I and II. We can see characteristic features of thermohaline eddy structure previously observed in the radial sections. The largest mean temperature anomalies in the composite AE are located within depth range of 200 $600 \mathrm{~m}\left(\sim 1.25^{\circ} \mathrm{C}\right)$ and $200-700 \mathrm{~m}\left(\sim 0.65^{\circ} \mathrm{C}\right)$ in the Region I and II respectively. The minimum temperature anomalies in the composite $\mathrm{CE}$ are found at the $\sim 600 \mathrm{~m}$ for the Region $\mathrm{I}\left(-1.9^{\circ} \mathrm{C}\right)$ 

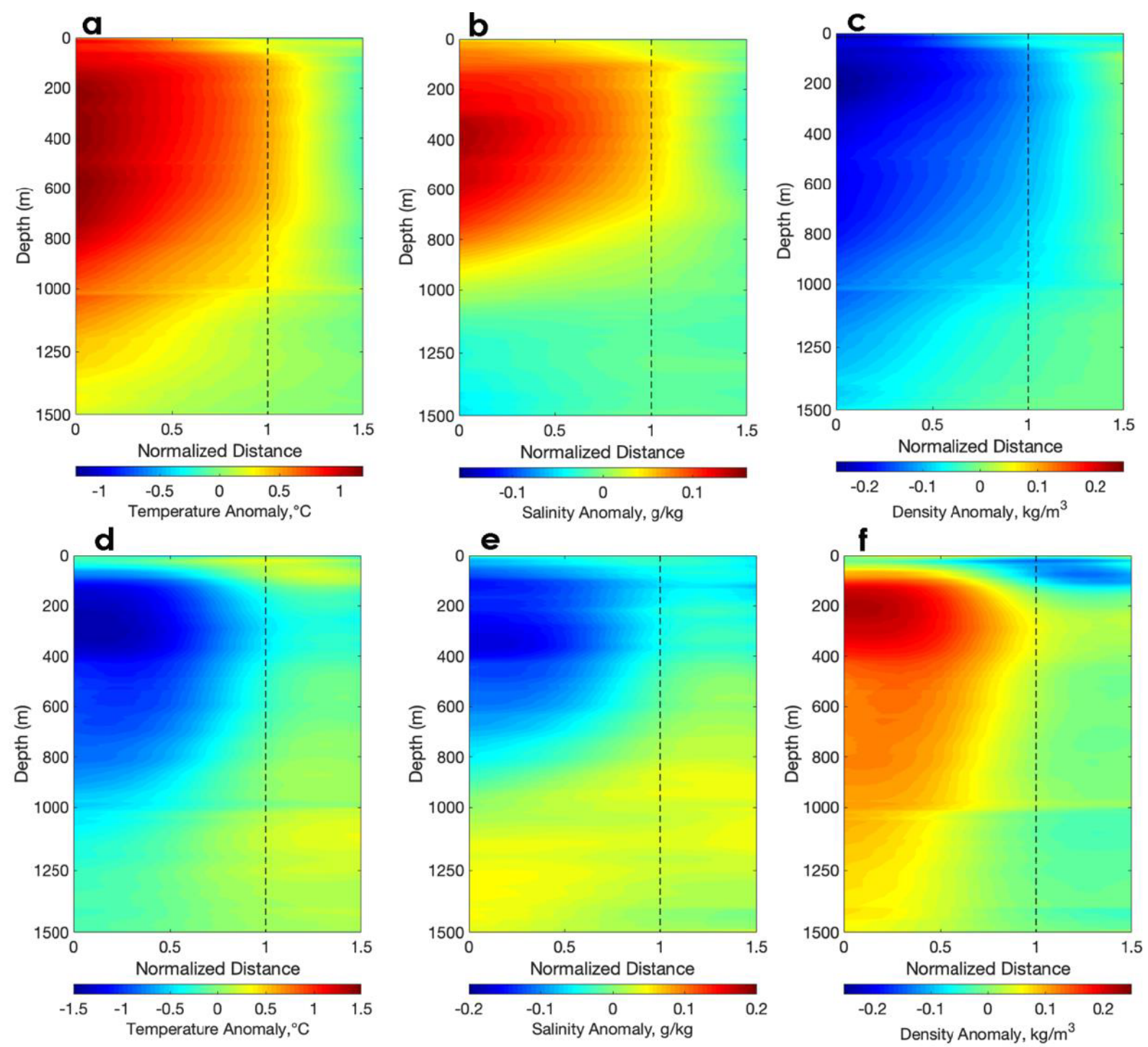

Figure 6. Radial cross-sections of temperature (a, d), salinity (b, e) and density (c, f) anomalies in the composite AE (top) and CE (bottom) (Region II).

and at $\sim 300 \mathrm{~m}$ for the Region II $\left(-1.45^{\circ} \mathrm{C}\right)$. The extrema of $T^{\prime} / S^{\prime}$ values in the composite $\mathrm{AE}$ are located at the depth level of about $400 \mathrm{~m}(0.15 \mathrm{~g} / \mathrm{kg}$ and $0.08 \mathrm{~g} / \mathrm{kg}$ for the Region I and II respectively). The extrema in the composite $\mathrm{CE}$ are found at the depth of $400 \mathrm{~m}(-0.2 \mathrm{~g} / \mathrm{kg})$ and 350 $\mathrm{m}(-0.18 \mathrm{~g} / \mathrm{kg})$ for the Regions I and II respectively (Figure 11b, Figure 11p). The profiles of mean density anomalies are mostly consistent with temperature anomalies which again demonstrates that density distribution of the study area is mostly driven by the temperature anomalies (Figure 11k, Figure 11f).
We can see that extrema of temperature, salinity and density anomalies in the CEs exceed in the absolute values the corresponding extrema in the AEs. This creates an asymmetry in the distribution of the thermohaline anomalies with a large shift towards negative temperature and salinity anomalies and positive density anomalies. This asymmetry is particularly prominent in eddy structures for Region I. It should also be noted that the averaged values of temperature and salinity anomalies in composite $\mathrm{CE}$ change the sign at a depth of about $1000 \mathrm{~m}$. This feature is observed in composite CEs for both regions (Figure 11p, Figure 11p). 

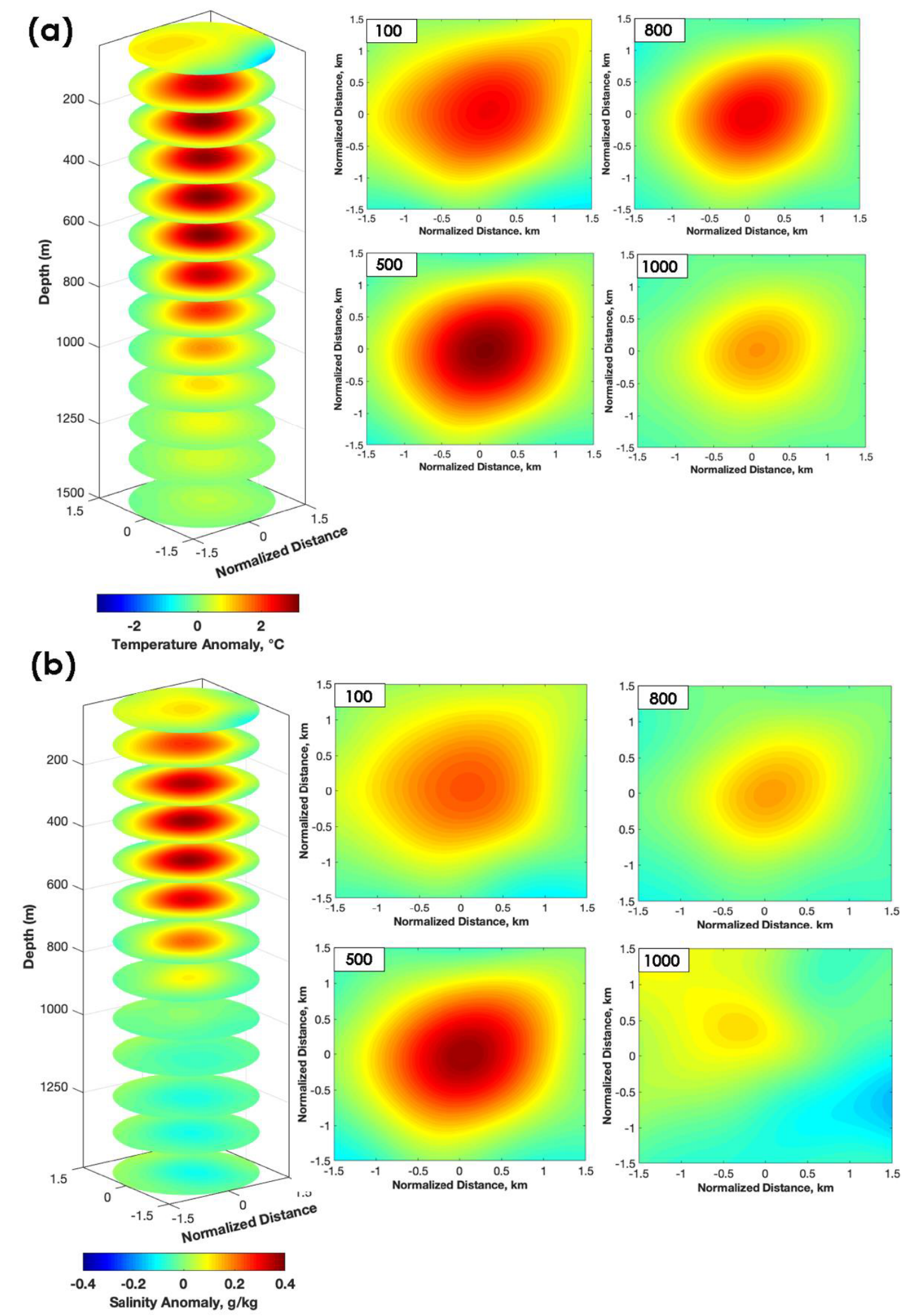

Figure 7. Three-dimensional temperature (a) and salinity (b) structure of the composite $\mathrm{AE}$ and horizontal distribution of temperature and salinity anomalies at the 100, 500, 800 and $1000 \mathrm{~m}$ (Region I). The $x$ and $y$ coordinates are normalized by eddy radius as in Figure 2 

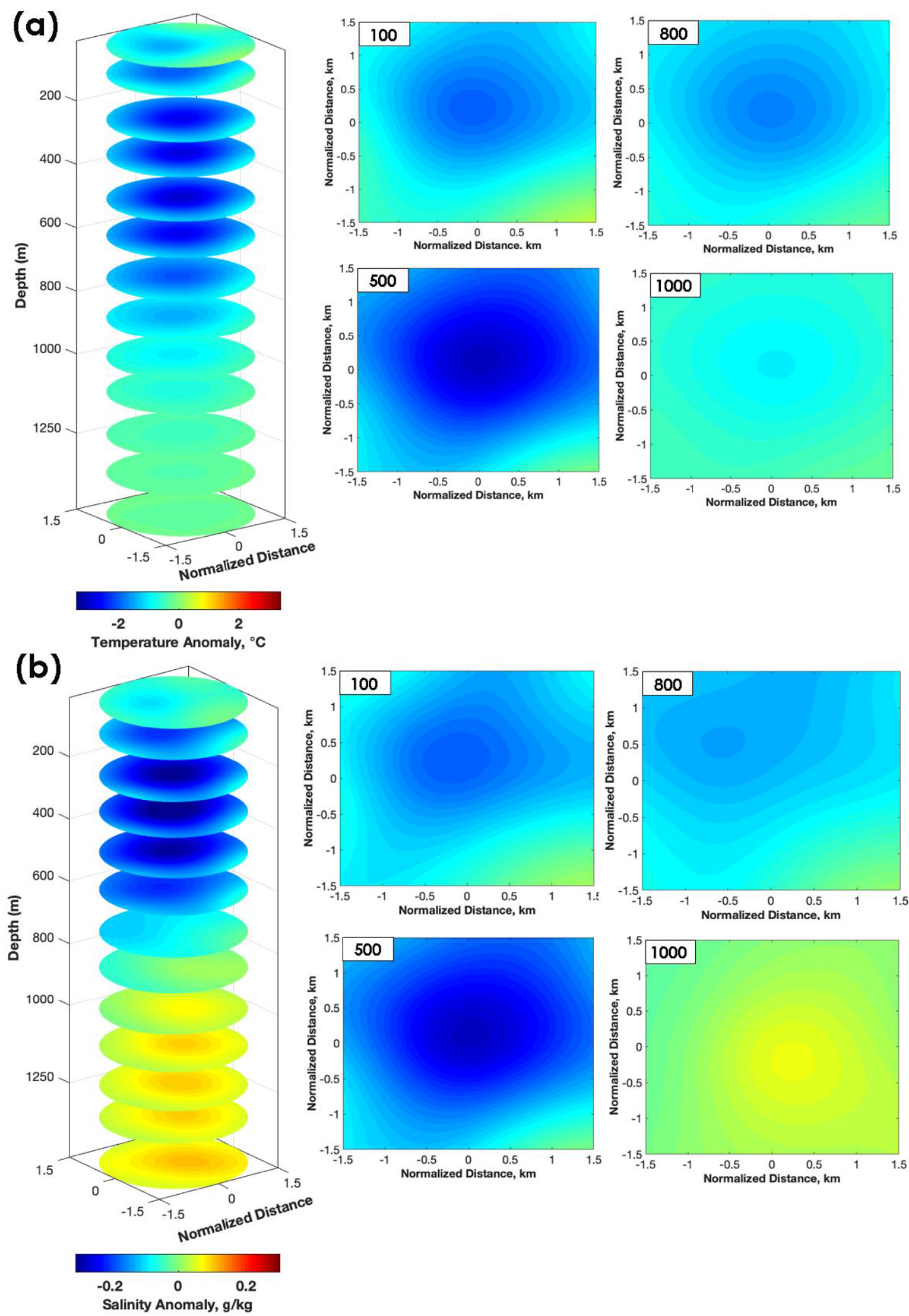

Figure 8. Three-dimensional temperature (a) and salinity (b) structure of the composite $\mathrm{CE}$ and horizontal distribution of temperature and salinity anomalies at the 100, 500, 800 and $1000 \mathrm{~m}$ (Region I). The $x$ and $y$ coordinates are normalized by eddy radius as in Figure 2, 
(a)
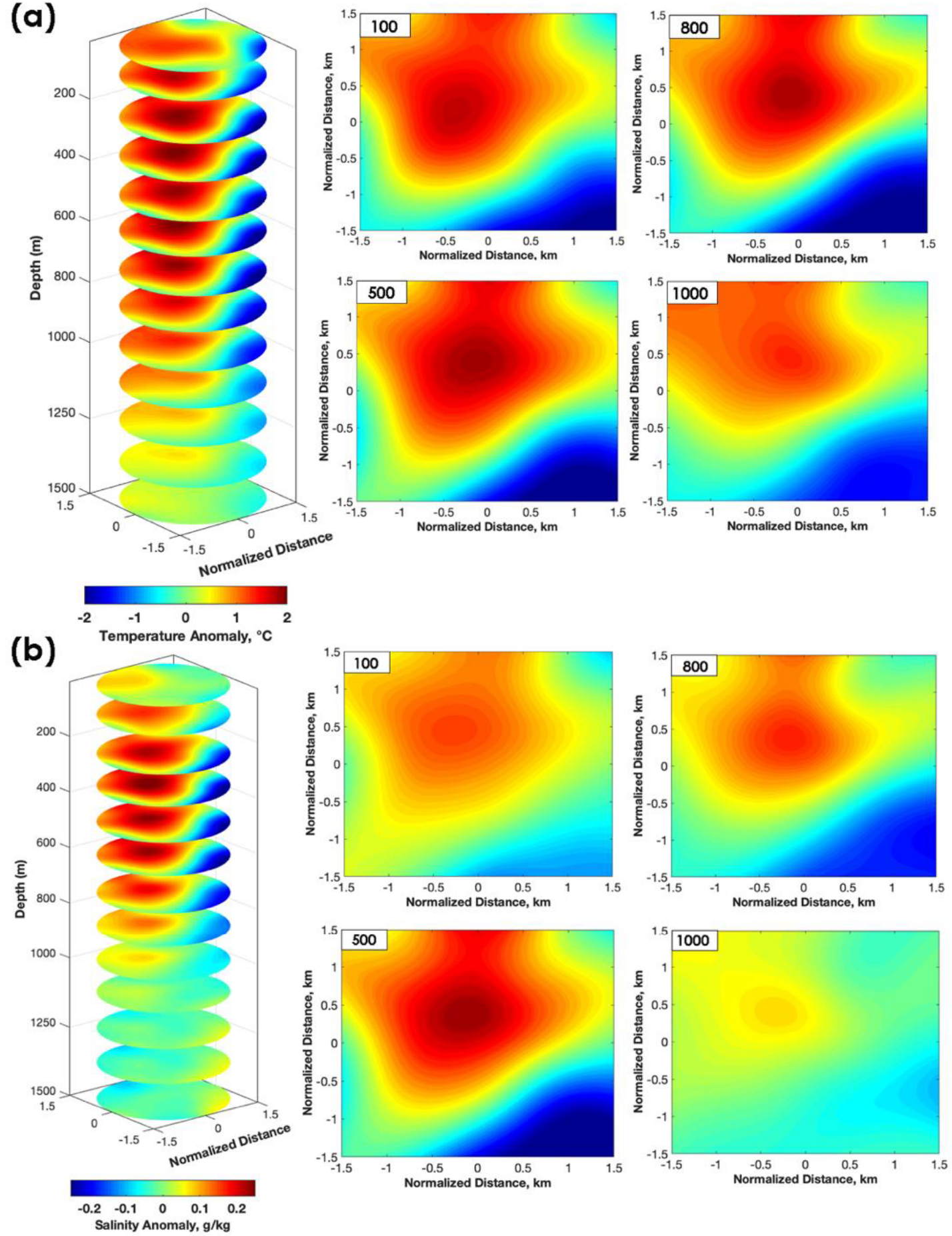

Figure 9. Three-dimensional temperature (a) and salinity (b) structure of the composite $\mathrm{AE}$ and horizontal distribution of temperature and salinity anomalies at the 100, 500, 800 and $1000 \mathrm{~m}$ (Region II). The $x$ and $y$ coordinates are normalized by eddy radius as in Figure 2 

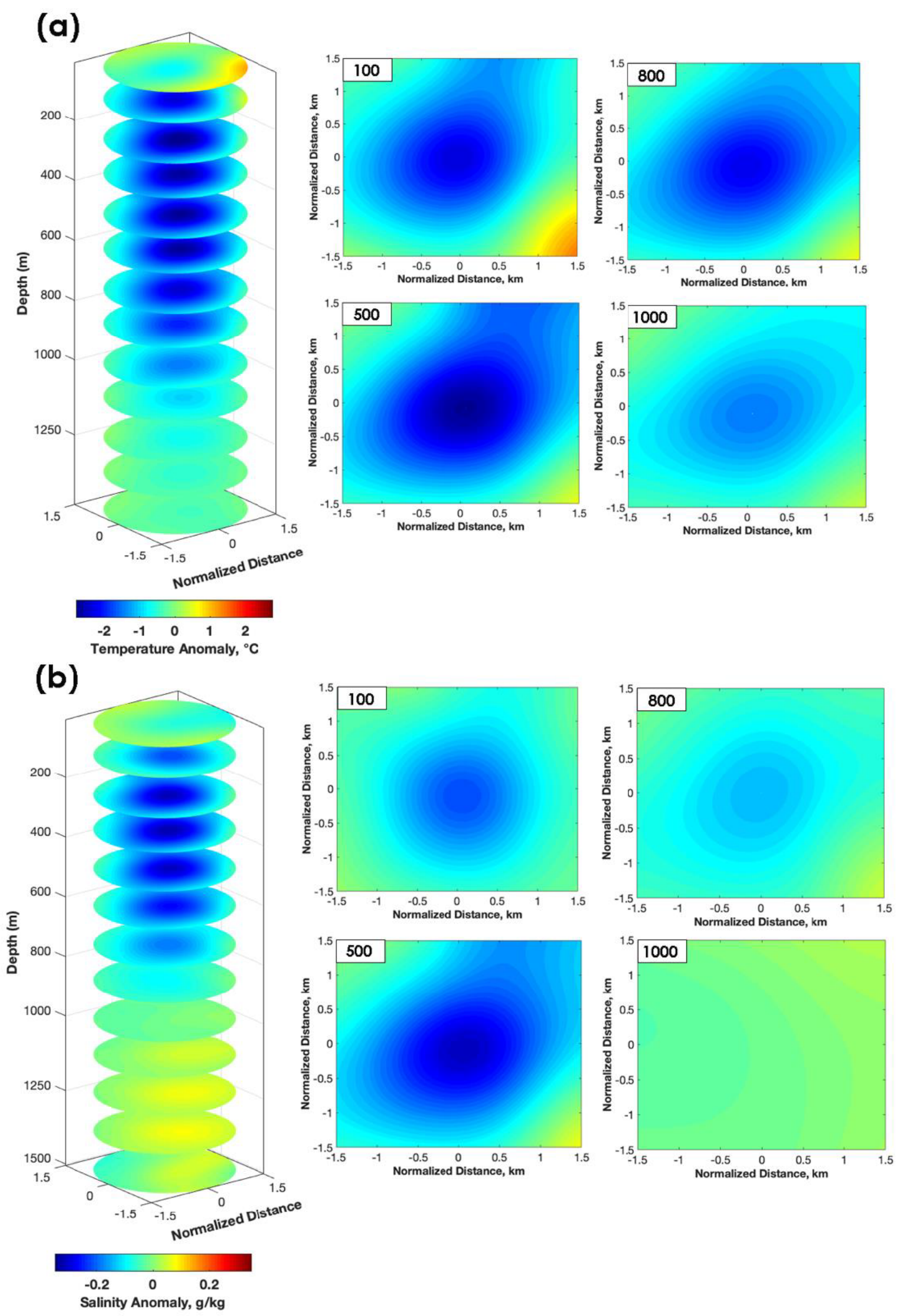

Figure 10. Three-dimensional temperature (a) and salinity (b) structure of the composite $\mathrm{CE}$ and horizontal distribution of temperature and salinity anomalies at the 100, 500, 800 and $1000 \mathrm{~m}$ (Region II). The $x$ and $y$ coordinates are normalized by eddy radius as in Figure 2. 

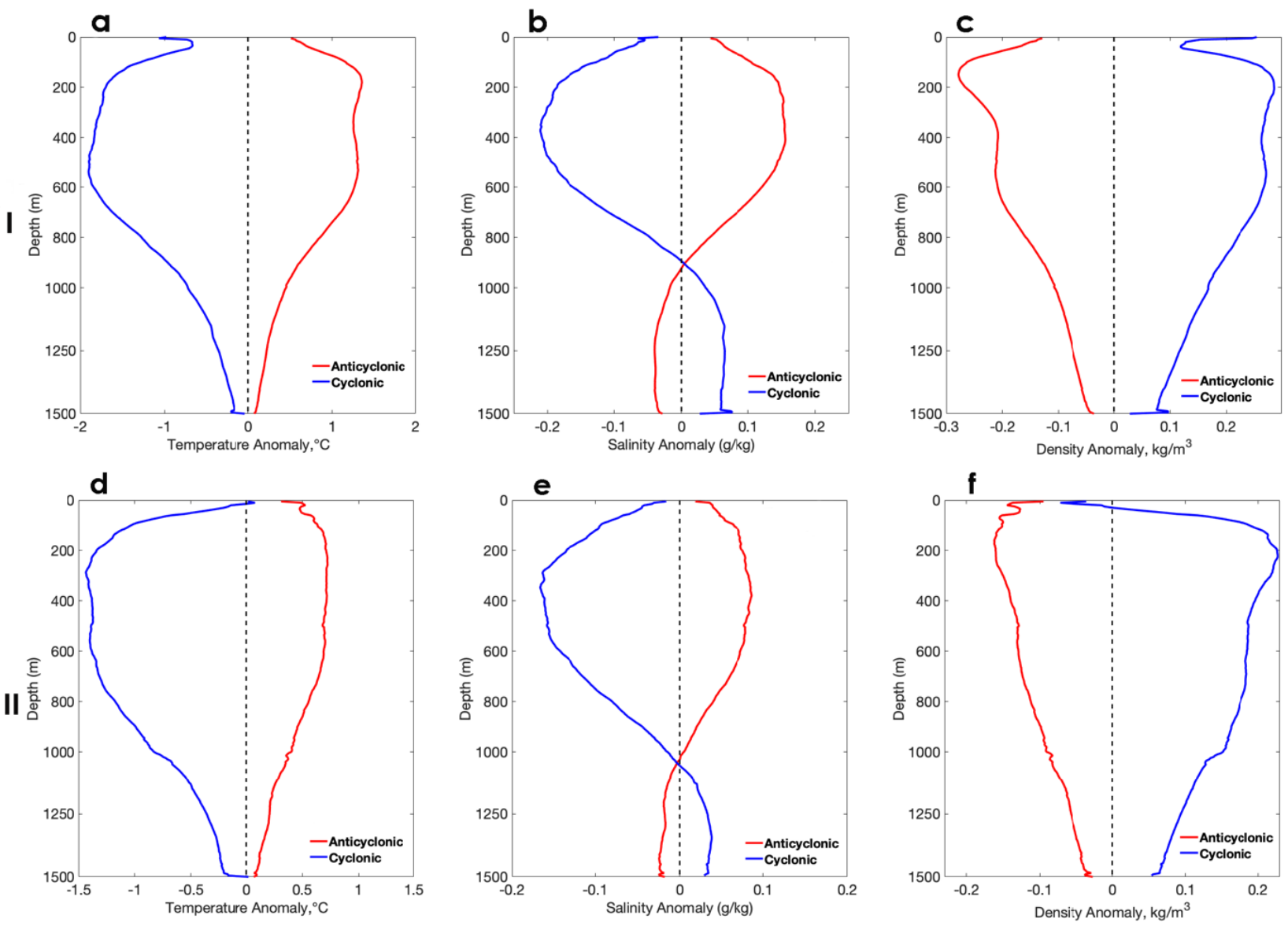

Figure 11. Mean vertical profiles of temperature (a), salinity (b) and density (c) anomalies averaged within $1 R$ for the composite AE and CE (Region I and II).

\section{Volume Transport and Heat and Salt Contents}

Based on the obtained three-dimensional structures we estimate volume, heat, and salt transported by the mesoscale eddies in the study region Table 1. The average radius of the AEs (according to the Mesoscale Eddy Trajectory Atlas) is $96.2 \pm 26.9 \mathrm{~km}$ in the Region I and $87.5 \pm 27.3 \mathrm{~km}$ in the Region II. The average radius of the CEs is $84.8 \pm 26.7 \mathrm{~km}$ and $73.4 \pm 23.4 \mathrm{~km}$ in Region I and II respectively.

Defining the lower boundary of the eddy is a challenging task. By the "lower boundary" of the eddy we mean the depth down to which eddy trap volume, heat, salt, and biogeochemical constituents. Different studies follow different approaches but in general, they all come down to the two methods. The first method is defining the spe- cific isotherm (or isohaline) as the threshold value defining the lower boundary of the eddy [Belonenko et al., 2020, Kubryakov et al., 2018; Travkin and Belonenko, 2019. This approach can be implemented along with a detailed analysis of the water masses transported by the eddies in the specific region. To define the lower eddy boundary using the second approach we need to estimate the ratio of the orbital eddy velocity $(v)$ and propagation speed of the eddy $(c)$. In this case, the trapping depth is defined as a depth where the ratio $v / c$ equals zero [Chaigneau et al., 2011, Flierl, 1981. The estimation of trapping depth of the Agulhas Rings plays a crucial role in the assessment of the Agulhas Leakage and ranges from $670 \mathrm{~m}$ to 1600 $\mathrm{m}$ in various studies [Duncombe Rae et al., 1992 , McCartney and Woodgate-Jones, 1991; Schmid et al., 2003, Van Sebille et al., 2010, Laxenaire et al., 2019. The broad range in the estimations of the trapping depth of the rings is due to the variation 
Table 1. Characteristics of a Composite AE and CE in the Region I and II

\begin{tabular}{lrrrr}
\hline & \multicolumn{2}{c}{ Region I } & \multicolumn{2}{c}{ Region II } \\
& AE & CE & CE \\
\hline Volume $\left(10^{13} \mathrm{~m}^{3}\right)$ & 3.49 & 2.71 & 2.4 & 1.69 \\
$\mathrm{HC}\left(10^{20} \mathrm{~J}\right)$ & 2.38 & -1.9 & 1.12 & -1.26 \\
$\mathrm{SC}\left(10^{12} \mathrm{~kg}\right)$ & 4.79 & -3.07 & 2.69 & -2.73 \\
Volume transport $(\mathrm{Sv})$ & 5.89 & 4.88 & 4.11 & 3.89 \\
\hline
\end{tabular}

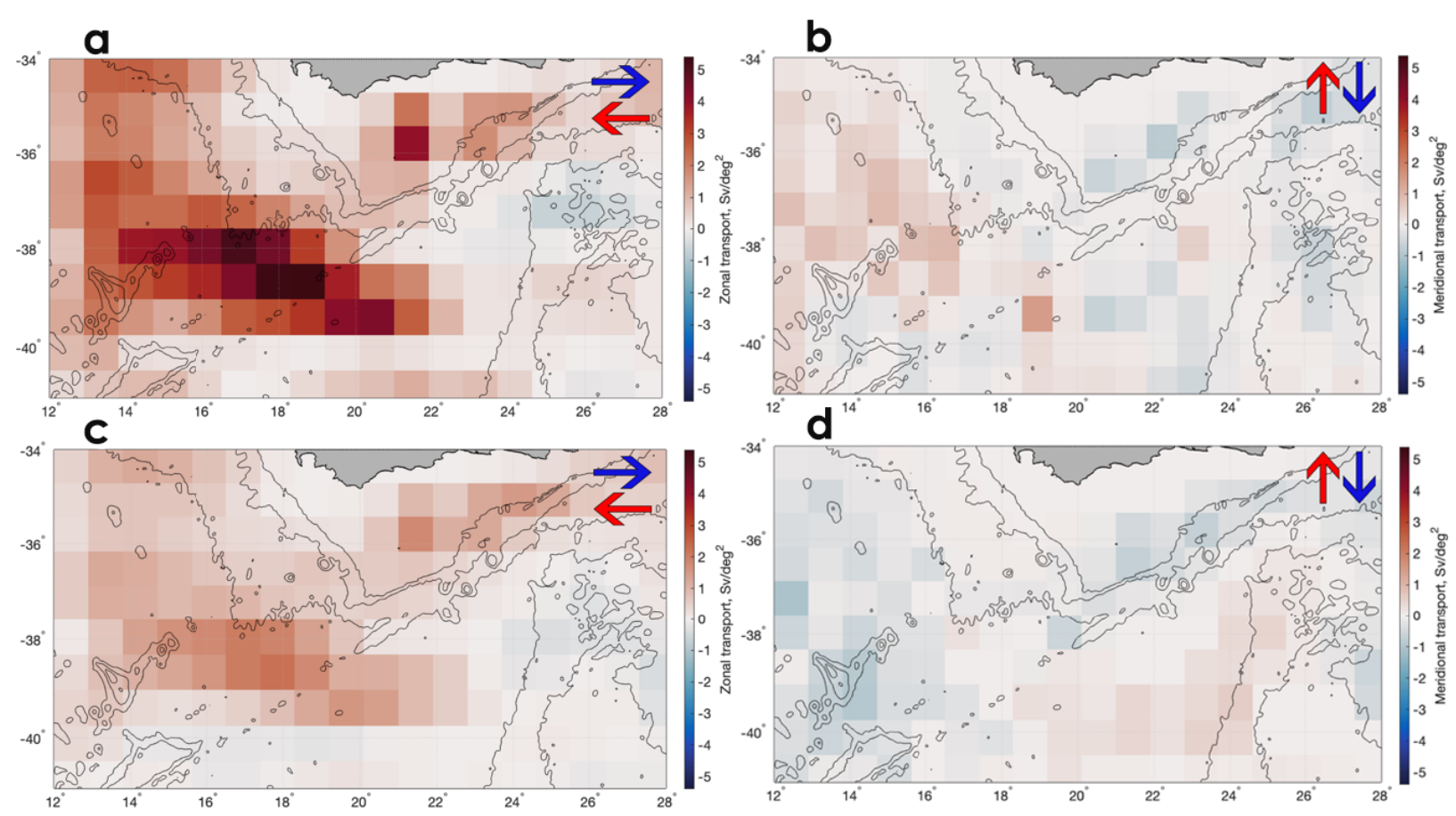

Figure 12. Zonal (a, c) and Meridional (b, d) eddy volume transport for the AEs (a, b) and CEs (c, d) calculated for every $1^{\circ} \times 0.8^{\circ}$ bin in the Agulhas Current region. The positive value refers to the westward transport; the negative value refers to the eastward transport.

of the spatial scales for the individual rings, as well as their dynamic and thermohaline characteristics. In this study, the lower boundary of the obtained composite eddy is defined as the location of the $T^{\prime} / S^{\prime}$ value the corresponding to about $10 \%$ of the maximum $T^{\prime} / S^{\prime}$ associated with eddies.

The lower boundary of the composite AE in the Region I is about $1200 \mathrm{~m}$. For the composite AE and $\mathrm{CE}$ in the Region II the location of the trapping depth is $\sim 1000 \mathrm{~m}$. Thus, the mean eddy volume in Region I is $3.49 \times 10^{13} \mathrm{~m}^{3}$ for the composite $\mathrm{AE}$ and $2.71 \times 10^{13} \mathrm{~m}^{3}$ for the composite $\mathrm{CE}$. For Region II this estimation is $2.4 \times 10^{13} \mathrm{~m}^{3}$ and $1.69 \times 10^{13} \mathrm{~m}^{3}$ for the composite $\mathrm{AE}$ and $\mathrm{CE}$ respectively. According to the Mesoscale Eddy Tra- jectory Atlas Product, the average eddy propagation speed is $0.05 / 0.048 \mathrm{~m} / \mathrm{s}$ and $0.047 / 0.053 \mathrm{~m} / \mathrm{s}$ for Region I and II respectively.

The total heat $(H C)$ and salt $(S C)$ contents transported by the composite $\mathrm{AE}$ and $\mathrm{CE}$ were calculated as follows [Chaigneau et al., 2011, Dong et al., 2017):

$$
\begin{aligned}
& H C=\rho C_{p} \int T^{\prime} d x d y d z \\
& S C=\rho C_{p} \int S^{\prime} d x d y d z
\end{aligned}
$$

where $C p=4200 \mathrm{~J} / \mathrm{kg} \mathrm{K}$ and $\rho=1025 \mathrm{~kg} / \mathrm{m}^{3}$ are specific heat capacity of the seawater and mean 
upper ocean density respectively; $T^{\prime}$ is the eddyinduced temperature anomaly, $S^{\prime}$ is the eddy-induced salinity anomaly.

In various studies, the estimates of the volume of the Agulhas Rings range from $1.53 \times 10^{13} \mathrm{~m}^{3}$ to $7.1 \times 10^{13} \mathrm{~m}^{3}$ [van Ballegooyen et al., 1994, Garzoli et al., 1999, Laxenaire et al., 2019 McDonagh et al., 1999, McCartney and Woodgate-Jones, 1991 . Malysheva et al., 2018, Schmid et al., 2003. The obtained assessment of the volume of the Agulhas Ring $\left(3.49 \times 10^{13} \mathrm{~m}^{3}\right)$ is most consistent with the results of a study McCartney and Woodgate-Jones $1991\left(3.6 \times 10^{13} \mathrm{~m}^{3}\right)$. According to the number of studies the range of the estimates of the heat and salt transported by the Agulhas Rings is $0.19 \times$ $10^{20} \mathrm{~J}-2.5 \times 10^{20} \mathrm{~J}$ for the heat estimates and $1.21 \times 10^{12} \mathrm{~kg}-13.1 \times 10^{12} \mathrm{~kg}$ for the salt estimates [van Ballegooyen et al., 1994] Duncombe Rae et al., 1996: Garzoli et al., 1999, Laxenaire et al., 2019. McCartney and Woodgate-Jones, 1991, McDonagh et al., 1999, Schmid et al., 2003.

Our assessment of the heat and salt trapped by the composite $\mathrm{AE}$ in the Region I $\left(2.38 \times 10^{20} \mathrm{~J}\right.$ and $4.79 \times 10^{12} \mathrm{~kg}$ ) is mostly consistent with the van Ballegooyen et al. $1994\left(2.36 \times 10^{20} \mathrm{~J}\right.$ and $4.59 \times 10^{12} \mathrm{~kg}$ ).

Figure 12 shows spatial distributions of the mean zonal and meridional eddy induced transport for CEs and AEs for the study region. Zonal eddyinduced transport has a general westward direction for the eddies of both polarities. The maximum value of the zonal eddy-induced transport is $5.38 \mathrm{~Sv} / \mathrm{deg}^{2}$ in the Agulhas Retroflection region (Figure 12a).

Following the patterns of the zonal eddy-induced transport, we can track typical propagation trajectories of the Agulhas Rings from the Agulhas Retroflection region to the Cape Basin (Figure 12a). Westward propagation of the zonal transport for AEs and CEs is also observed in the central part of the shelf zone (Figure 12a, Figure 12k) with the maximum values of $4 \mathrm{~Sv} / \mathrm{deg}^{2}$ for AEs and $1.77 \mathrm{~Sv} / \mathrm{deg}^{2}$ for CEs. The eastern direction of the eddy-induced transport is predominant in the area of the Agulhas Return Current (across the $40^{\circ} \mathrm{S}$ ) and in the Agulhas Plateau region. At the northwest area of the Agulhas Plateau, the intensity of the eastern eddy-induced transport reaches $0.67 \mathrm{~Sv} / \mathrm{deg}^{2}$ for AEs and $0.68 \mathrm{~Sv} / \mathrm{deg}^{2}$ for CEs.

An interesting feature of the meridional eddyinduced transport in the study region is the pre- dominance of the northward transport for AEs in the area of the Cape Basin and to the east of the Agulhas Plateau (Figure 12b), while for CEs the southward direction of the meridional transport prevails in this area (Figure 12 $\mathrm{d}$ ). The predominant southward direction of the meridional transport is also observed in the shelf zone.

\section{Conclusion}

By implementing the method of colocalization of the altimetry data and temperature and salinity profiles we obtained the averaged composite thermohaline structures of the AEs and CEs in the Agulhas Current region, as well as the averaged estimations of the heat and salt transported by the Agulhas Rings.

The use of satellite altimetry data along with the Argo profiles presents a powerful tool for obtaining the three-dimensional structures of the mesoscale eddies. It also provides the opportunity to assess an estimation of the inter-ocean exchange based on the eddy's volume and associated anomalies.

The observed intensification of eddy dissipation processes can be caused by the topographic barriers, such as the Agulhas Plateau or the Agulhas Ridge. Schouten et al. 2000 and Hall and Lutjeharms 2011 demonstrated that ridges connecting the African continent with the Mid-Atlantic Ridge in the South Atlantic significantly affect the propagation patterns of the mesoscale eddies in the Agulhas region. While crossing the ridges rings lose almost $70 \%$ of their kinetic energy and can split into smaller eddies most of which never leave the area of the Cape Basin [Schouten et al., 2000.

The internal structure of the obtained composite AE in Region I is characterized by a subsurface core which has been previously identified as Mode Waters [Arhan et al., 1999, Laxenaire et al., 2019. Souza et al., 2018. This thick core accumulates the strongest heat and salt anomalies which are responsible for the advection of a large amount of heat and salt from the Indian Ocean to the South Atlantic Ocean. In both composite AE and CE in the surface layer (down to $50 \mathrm{~m}$ ) the temperature and salinity anomalies almost undetectable and the rapid increase of the thermohaline anomalies starts from about $100 \mathrm{~m}$. Nencioli et al. 2018 and Laxenaire et al. 2019 showed that for the eddies in 
the Agulhas region in the layer of $\sim 0-150 \mathrm{~m}$ the strong seasonal signal is observed and specifically for the Agulhas Rings the water in this layer is not a part of the eddy core.

The temperature and salinity anomalies in the composite $\mathrm{AE}$ are concentrated within the depth range of $100-700 \mathrm{~m}$ and reach $1.94^{\circ} \mathrm{C}$ and $0.23 \mathrm{~g} / \mathrm{kg}$ in Region I. For Region II the eddy core in the composite $\mathrm{AE}$ is located in the depth range of 200-800 $\mathrm{m}$ with a maximum value of $1.17^{\circ} \mathrm{C}$ and $0.15 \mathrm{~g} / \mathrm{kg}$. The core of the composite CE in the Region I concentrated in the layer $150-700 \mathrm{~m}$ with the temperature and salinity anomalies reach $-2.5^{\circ} \mathrm{C}$ and $-0.25 \mathrm{~g} / \mathrm{kg}$ respectively. The depth of the eddy core in the Region I in the composite CE is about $400 \mathrm{~m}$ with the minimum temperature and salinity anomaly of $-1.38^{\circ} \mathrm{C}$ and $-0.17 \mathrm{~g} / \mathrm{kg}$ located at $400 \mathrm{~m}$ and $250 \mathrm{~m}$ respectively.

The estimation of the average volume of the Agulhas Rings (composite AE in Region I) based on the obtained composite structure is consistent with the results of a study McCartney and WoodgateJones [1991. Our assessment of the heat and salt trapped by the composite $\mathrm{AE}$ in Region I $\left(2.38 \times 10^{20} \mathrm{~J}\right.$ and $\left.4.79 \times 10^{12} \mathrm{~kg}\right)$ is mostly consistent with the van Ballegooyen et al. 1994 $\left(2.36 \times 10^{20} \mathrm{~J}\right.$ and $\left.4.59 \times 10^{12} \mathrm{~kg}\right)$.

Westward propagation of the zonal eddy-induced transport for AEs and CEs is observed in the Agulhas Retroflection region, Cape Basin, and in the central part of the shelf zone with the maximum values of $4 \mathrm{~Sv} / \mathrm{deg}^{2}$ for $\mathrm{AEs}$ and $1.77 \mathrm{~Sv} / \mathrm{deg}^{2}$ for CEs. The eastern direction of the eddy-induced transport is predominant in the area of the Agulhas Return Current and in the Agulhas Plateau region. A prominent feature of the meridional eddyinduced transport in the study region is the predominance of the northward transport for AEs in the area of the Cape Basin and to the east of the Agulhas Plateau while for CEs the southward direction of the meridional transport prevails in this area.

From the patterns of the zonal eddy induced transport (Figure 12) we can see the typical paths of the eddy propagations from the Agulhas Retroflection region to the Cape Basin which are associated with the Agulhas Leakage. This process plays a significant role in climate variability and predictability and impacts the Atlantic meridional overturning circulation (AMOC).
Acknowledgments. This research was supported by the by the Russian Foundation for Basic Research (project No. 20-05-00066). The publication was funded by Saint Petersburg State University, project N 75295423.

\section{References}

Arhan, M., H. Mercier, J. R. E. Lutjeharms (1999), The disparate evolution of three Agulhas rings in the South Atlantic Ocean, Journal of Geophysical Research Oceans, 104, No. C9, 987, Crossref

van Ballegooyen, R. C., et al. (1994), Eddy fluxes of heat and salt from the southwest Indian Ocean into the southeast Atlantic Ocean: A case study, Journal of Geophysical Research, 99, No. C7, 14,053-14,070, Crossref

Barnes, S. L. (1973), Mesoscale objective map analysis using weighted time-series observations (NOAA Tech. Memo. ERL NSSL-69, 60 pp. National Severe Storm Laboratory, Norman, OK.

Belonenko, T., V. Zinchenko, et al. (2020), Evaluation of Heat and Salt Transports by Mesoscale Eddies in the Lofoten Basin, Russ. J. Earth Sci., 20, ES6011, Crossref

Boebel, O., J. R. E. Lutjeharms, et al. (2003), The Cape Cauldron: a regime of turbulent interocean exchange, Deep-Sea Research II, 50, No. 1, 57-86, Crossref

Byrne, D. A., A. L. Gordon, W. F. Haxby (1995), Agulhas eddies: A synoptic view using Geosat ERM data, Journal of Physical Oceanography, 25, No. 5, 902917, Crossref

Chaigneau, A., M. Le Texier, et al. (2011), Vertical structure of mesoscale eddies in the eastern South Pacific Ocean: A composite analysis from altimetry and Argo profiling floats, J. Geophys. Res., 116, C11025, Crossref

Chelton, D. B., M. G. Schlax, R. M. Samelson (2011), Global observations of nonlinear mesoscale eddies, Prog. Oceanogr., 91, 167-216, Crossref

Chelton, D. B., M. G. Schlax, et al. (2007), Global observations of large oceanic eddies, Geophysical Research Letters, 34, 15, Crossref

Dencausse, G., M. Arhan, S. Speich (2010), Routes of Agulhas rings in the southeastern Cape Basin, Deep Sea Research Part I: Oceanographic Research Papers, 57, No. 11, 1406-1421, Crossref

Dong, D., P. Brandt, et al. (2017), Mesoscale eddies in the Northwestern Pacific Ocean: Threedimensional eddy structures and heat/salt transports, Journal of Geophysical Research: Oceans, 122, 97959813, Crossref

Dong, C., J. C. McWilliams, et al. (2014), Global heat and salt transports by eddy movement, Nature Communications, 3294, Crossref 
Duncombe Rae, C., F. Shillington, et al.

(1992), An Agulhas ring in the South Atlantic Ocean and its interaction with the Benguela upwelling frontal system, Deep Sea Research Part A. Oceanographic Research Papers, 39, 2009-2027, Crossref

Duncombe Rae, C., S. Garzoli, A. Gordon (1996), The eddy field of the southeast Atlantic Ocean: A statistical census from the Benguela Sources and Transports Project, J. Geophys. Res.: Oceans, 101, No. C5, 11,949-11,964, Crossref

Flierl, G. R. (1981), Particle motions in largeamplitude wave fields, Geophys. Astrophys. Fluid Dyn., 18, 39-74, Crossref

Garzoli, S. L., P. L. Richardson, et al.

(1999), Three Agulhas rings observed during the Benguela Current Experiment, Journal of Geophysical Research, 104, 20,971-20,985, Crossref

Gordon, A. L., J. R. Lutjeharms, M. L. Griindlingh (1987), Stratification and circulation at the Agulhas Retroflection, Deep Sea Research Part A. Oceanographic Research Papers, 34, No. 4, 565599, Crossref

Hall, C., J. R. E. Lutjeharms (2011), Cyclonic eddies identified in the Cape Basin of the South Atlantic Ocean, J. Marine Systems, 85, 1-10, Crossref

He, Q., H. Zhan, et al. (2018), A new assessment of mesoscale eddies in the South China Sea: Surface features, three-dimensional structures, and thermohaline transports, Journal of Geophysical Research: Oceans, 123, 4906-4929, Crossref

Keppler, L., S. Cravatte, et al. (2018), Observed characteristics and vertical structure of mesoscale eddies in the southwest tropical Pacific, Journal of Geophysical Research: Oceans, 123, 2731-2756, Crossref

Kubryakov, A. A., A. V. Bagaev, et al.

(2018), Thermohaline structure transport and evolution of the Black Sea eddies from hydrological and satellite data, Progress in Oceanography, 167, 44-63, Crossref

Laxenaire, R., S. Speich, S. Alexandre (2019), Evolution of the thermohaline structure of one Agulhas Ring reconstructed from satellite altimetry and Argo floats, Journal of Geophysical Research: Oceans, 124, 8969-9003, Crossref

Lutjeharms, J. R. E. (2006), The Agulhas Current, 330 pp. Springer, Berlin, Heidelberg.

Lutjeharms, J. R. E. (2007), Three decades of research on the greater Agulhas Current, Ocean Science, 3, No. 1, 129-147, Crossref

Lutjeharms, J. R. E., R. C. van Ballegooyen (1988), The retroflection of the Agulhas Current, J. Physical Oceanography, 18, 1570-1583, Crossref

Lutjeharms, J. R. E., H. R. Valentine (1988), Evidence for persistent Agulhas rings southwest of Cape Town, South African, J. Science, 84, 781-783.

Malysheva, A. A., A. V. Koldunov, et al. (2018), Agulhas Leakage Eddies based on the altimetry data, Uchjonye Zapiski RGGMU, 52, 154-170. (in Russian)
McCartney, M. S., M. Woodgate-Jones (1991), A deep-reaching anticyclonic eddy in the subtropical gyre of the eastern South Atlantic, Deep Sea Research Part A. Oceanographic Research Papers, 38, 411443, Crossref

McDonagh, E. L., K. J. Heywood, M. P. Meredith (1999), On the structure, paths, and fluxes associated with Agulhas rings, Journal of Geophysical Research: Oceans, 104, No. C9, 21,007-21,020, Crossref

Monin, A. S., G. M. Zhiharev (1990), Ocean Eddies, Uspekhi Fizicheskikh Nauk, 160, No. 5, 147, (in Russian) Crossref

Nencioli, F., G. Dall'Olmo, G. D. Quartly (2018), Agulhas ring transport efficiency from combined satellite altimetry and Argo profiles, Journal of Geophysical Research: Oceans, 123, No. 8, 5874-5888, Crossref

Sandalyuk, N. V., T. V. Belonenko (2018), Mesoscale vortex dynamics in the Agulhas Current from satellite altimetry data, Sovremennye Problemy Distantsionnogo Zondirovaniya Zemli iz Kosmosa, 15, No. 5, 179-190, (in Russian)Crossref

Sandalyuk, N. V., A. Bosse, T. V. Belonenko (2020), The 3-D structure of mesoscale eddies in the Lofoten Basin of the Norwegian Sea: A composite analysis from altimetry and in situ data, Journal of Geophysical Research: Oceans, 125, e2020JC016331, Crossref

Schmid, C., O. Boebel, W. Zenk, et al. (2003), Early evolution of an Agulhas Ring, Deep Sea Research Part II: Topical Studies in Oceanography, 50, No. 1, 141-166, Crossref

Schouten, M. W., W. P. M. de Ruijter, et al. (2000), Translation, decay and splitting of Agulhas rings in the southeastern Atlantic Ocean, Journal of Geophysical Research, 105, No. C9, 21,913-21,925, Crossref

van Sebille, E., P. J. van Leeuwen (2007), $\quad$ Fast northward energy transfer in the Atlantic due to Agulhas rings, Journal of Physical Oceanography, 37, No. 9, 2305-2315, Crossref

van Sebille, E., P. J. van Leeuwen, et al. (2010), On the fast decay of Agulhas rings, J. Geophys. Res., 115, C03010, Crossref

Souza, J. M. A. C., C. de Boyer Montegut, et al. (2011), Estimation of the Agulhas ring impacts on meridional heat fluxes and transport using ARGO floats and satellite data, Geophysical Research Letters, 38, L21602, Crossref

de Souza, A. G. Q., R. Kerr, J. L. L. de Azevedo (2018), On the influence of subtropical mode water on the South Atlantic Ocean, Journal of Marine Systems, 185, 13-24, Crossref

Schlax, M. G., D. B. Chelton (2016), The "Growing Method" of Eddy Identification and Tracking in Two and Three Dimensions, College of Earth, Ocean and Atmospheric Sciences Oregon State University, Corvallis, Oregon. 
Travkin, V. S., T. V. Belonenko (2019), Seasonal variability of mesoscale eddies of the Lofoten Basin using satellite and model data, Russian Journal of Earth Sciences, 19, No. 5, ES5004, Crossref

Wells, N. C., V. O. Ivchenko, S. E. Best (2000), Instabilities in the Agulhas Retroflection Current system: A comparative model study, J. Geophys. Res., 105, No. C2, 3233-3241, Crossref

Williams, S., M. Hecht, et al. (2011), Visualization and analysis of eddies in a global ocean simulation, Comput. Graphics Forum, 30, 991-1000, Crossref

Willis, J. K., L.-L. Fu (2008), Combining altimeter and subsurface float data to estimate the timeaveraged circulation in the upper ocean, J. Geophys. Res., 113, C12017, Crossref

Yang, G., F. Wang, et al. (2013), Mesoscale eddies in the northwestern subtropical Pacific Ocean: Sta- tistical characteristics and three-dimensional structures, Journal of Geophysical Research: Oceans, 118, 1906-1925, Crossref

Yu, L.-S., A. Bosse, et al. (2017), The Lofoten Basin eddy: Three years of evolution as observed by Seagliders, J. Geophys. Res. Oceans, 122, 68146834, Crossref

Zhang, Z., Y. Zhang, et al. (2013), Universal structure of mesoscale eddies in the ocean, Geophys. Res. Lett., 40, 3677-3681, Crossref

Corresponding author:

Nikita Sandalyuk, Saint Petersburg State University, 7-9, Universitetskaya nab., Saint Petersburg 199034, Russia.(n.sandalyuk@spbu.ru) 